\title{
Zwrot polityczny w literaturze rosyjskiej, czyli ,Lewy Front Sztuki” według Zachara Prilepina
}

\begin{abstract}
Roman Katarzyna Urszula, Zwrot polityczny w literaturze rosyjskiej, czyli „Lewy Front Sztuki" wedtug Zachara Prilepina (A Political Turn in Russian Contemporary Literature or „Left Front of the Arts” by Zakhar Prilepin). „Poznańskie Studia Slawistyczne” 6. Poznań 2014. Publishing House Science and Innovate, pp. 229-242. ISBN 978-83-63795-51-1. ISSN 2084-3011.

The paper concerns Russian contemporary politically engaged literature and takes into consideration the writings of an acclaimed Russian prose-writer, radical anti-Kremlin opposition activist Zakhar Prilepin. A political turn in Russian contemporary literature is a way of raising an objection to the political authorities, who bring an incessant pressure on the society to reproduce the official public discourse. It is also the act of uniting particularities of aesthetics, existence and politics, as well as breaking with the vision of literature distanced from the public issues. The common ground for Russian writers' political commitment is a resistance to the postmodernism paradigm connected with an attempt to define the conditions and mechanisms of new ideology (in the „,new realism” current). Deeply political writings of Prilepin seem to be an anti-liberal and anti-individualistic rebellion, as well as a thorough critical study of Russian contemporary society. The revolutionary prose-writer is against the doctrine of cultural pluralism, the activities of neo-liberal ruling elite, the growing political authority of Russian middle class and the dominant vision of collective memory.
\end{abstract}

Keywords: political turn; contemporary Russian literature; Zakhar Prilepin; politically engaged literature; New realism current

\section{Uwagi wstępne}

Zakreślenie granic pojęcia literatury zaangażowanej oraz próba (re)konstrukcji jej założeń, implikacji i znaczenia są od pewnego czasu przedmiotem debaty w literaturoznawstwie, socjologii, a także antropologii literatury (Dunin 2004; Ziętek-Maciejczyk et al. 2006; Czapliński 2009; Olejniczak et al. 2012). Wielogłos opinii na temat zakresu tego pojęcia ostatecznie łączy się we wspólny postulat znalezienia aktualnej, 
ponowoczesnej definicji. Celem niniejszej pracy nie jest jednak opis historii i przegląd rozmaitych formuł społecznego i politycznego zaangażowania literatury. Artykuł ma być przyczynkiem do analizy najnowszej literatury rosyjskiej, w której można dostrzec zwrot ku polityce. Wyrazistym przykładem tej tendencji jest proza pisarza i społecznika Zachara Prilepina, przedstawiciela radykalnego skrzydła zaangażowanych rosyjskich literatów.

Rozważania podjęte w artykule dotyczą zatem związków między literaturą a polityką. Podstawą teoretyczną, porządkującą dociekania, jest koncepcja Pierre'a Bourdieu, który wyznacza trzy modele relacji sztuki do polityki. Sztukę (w tym literaturę) zaangażowaną miałoby charakteryzować jednoznaczne wskazywanie programu politycznego (Bourdieu 2001: 329-340).

\section{2. „Spojrzałem wokół siebie - duszę moją zraniło ludzkie cierpienie"}

Wielu badaczy rosyjskiej kultury zauważa, że jedną z właściwości literatury rosyjskiej, co najmniej od końca XVIII wieku², jest jej wymiar społeczny, otwierający pole dla myśli politycznej - krytycznej i opozycyjnej wobec autorytarnej władzy³. Najczęściej zakładają oni, że jest to typowy rys literatury rosyjskiej (Iwanowa 2003, 2011), wyraz „,Szerokiej duszy” rosyjskiej. Z punktu widzenia

${ }^{1}$ Pierwsze zdanie z Podróży z Petersburga do Moskwy Aleksandra Radiszczewa (wydanie polskie 1954).

2 Rok wydania Podróży z Petersburga do Moskwy (1790) jest traktowany jako symboliczna data narodzin inteligencji rosyjskiej, A. Radiszczewa uznaje się za jej pierwszego przedstawiciela (cf. Bierdiajew 2005: 19). Fundamentem tożsamości tej unikatowej w Europie warstwy społecznej było poświęcanie się wspólnej sprawie - działaniu na rzecz emancypacji ludu. Najważniejszym komponentem ich etosu jako rzeczników i opiekunów ludu było zatem gorliwe zaangażowanie społeczne i polityczne (Smoleń 2010).

${ }^{3} \mathrm{Na}$ temat zaangażowania społecznego i politycznego literatury rosyjskiej (cf. Wołodźko-Butkiewicz 1995, 2004).

4 To przekonanie pojawia się u Nikołaja Bierdiajewa (2005: 56-71) w rozdziale Literatura rosyjska i jej proroctwa. Bierdiajew wplata również komentarz na temat istotnego miejsca literatury rosyjskiej w historii rosyjskiej myśli XIX i początku XX wieku w pracy Rosyjska Idea. Pogląd o profetycznym charakterze literatury rosyjskiej powtarzać się będzie później w wypowiedziach rosyjskich literaturoznawców i kulturoznawców. 
kulturowej teorii literatury ${ }^{5}$, przeniesienie dyskusji na obszar literatury było raczej wynikiem braku alternatywnego forum dla debaty politycznej. Tendencja ta najjaskrawiej uwidoczniła się w XIX wieku, kiedy nowe prądy społeczne i intelektualne, przenikające do Rosji, komentowali przede wszystkim literaci ${ }^{6}$. W XX wieku literatura była $\mathrm{z}$ jednej strony katalizatorem zmian społecznych (głównie za sprawą tzw. grubych czasopism literackich ${ }^{7}$ ), a z drugiej żyrantem obowiązującej ideologii. Stąd bierze się przekonanie rosyjskich badaczy o literaturocentrycznym charakterze ich kultury (Bierg 2000, Nakoneczny 2007: 84, 87).

Pierwszym odruchem twórców w latach 90. XX wieku było zerwanie z politycznością literatury. Dominującym nurtem literackim w Rosji stał się wówczas postmodernizm, oznaczający m.in. autotematyzm oraz uwolnienie literatury od celów pozaliterackich. Bezpośrednio po upadku Związku Radzieckiego pisarze kategorycznie odcięli się od przymusu zaangażowania, zanurzając się w prywatność, jednakże po roku 2000 nie mogli już ignorować wyzwań postsocjalistycznej rzeczywistości. Nastąpiło ponowne otwarcie literatury rosyjskiej na kwestie polityczne, ideologiczne i społeczne - literatura rosyjska znów przeistoczyła się w manifest zaangażowania ${ }^{8}$.

Polityczne odczytanie działalności artystycznej literatów-społeczników, takich jak Zachar Prilepin, Dmitrij Bykow czy Siergiej Szargunow, pozwala widzieć w niej odpowiedź na problem pustki tożsamościowej po upadku

5 W ujęciu Ryszarda Nycza kulturowa teoria literatury zakłada, że niemożliwe stało się mówienie o literaturze w kategoriach nieuwarunkowanego kulturowo, autonomicznego, jednostkowego dzieła sztuki (Nycz 2006: 21). Ponadto badania kulturowe odżegnują się od postrzegania literatury jako ekspresji prywatnej osobowości. W tym ujęciu literatura jest jedną z wielu praktyk symbolicznych, poddanych społecznym regułom produkcji i kontroli (Burzyńska, Markowski 2006: 539).

${ }^{6}$ Należy nadmienić, że problem postępowej, ideowej inteligencji (przyszłych dekabrystów), szeroko komentuje Aleksander Gribojedow w Mądremu biada (1824); Iwan Turgieniew w utworze Ojcowie i dzieci (1862) opisuje nowe pokolenie społeczników, późniejszej radykalnej inteligencji; zagadnienie socjalizmu połowy XIX w. pojawia się u Nikołaja Czernyszewskiego w powieści Co robić (1863), a rodzący się socjalizm rewolucyjny ocenia Fiodor Dostojewski w Biesach (1871). Trzeba przy tym zaznaczyć, że interpretacja polityczna nie jest jedyną możliwością odczytywania dzieł klasyki literatury rosyjskiej.

7 „Tołstyj żurnał” - dosłownie ,grube czasopismo” to popularny w Rosji przedrewolucyjnej oraz w Związku Radzieckim typ czasopisma literacko-artystycznego i społeczno-politycznego (zazwyczaj miesięcznika) o dużej objętości. Obecnie wydawane najczęściej w formie elektronicznej.

${ }^{8}$ Mimo że nurt literatury zaangażowanej nie dominuje we współczesnej literaturze rosyjskiej, w ostatnich latach można zaobserwować jego wyraźną obecność. 
Związku Radzieckiego oraz na negatywne społeczne skutki transformacji ustrojowej lat 90. Zaangażowanie autorów w debatę na temat rozbitej tożsamości zbiorowej społeczeństwa rosyjskiego wiąże się z upolitycznieniem tekstów literackich. Co znamienne, wymienieni pisarze poszukiwali jednej wspólnej narracji. Celem dla rosyjskich pisarzy społecznie zaangażowanych, kategorycznie odcinających się od estetyki, poetyki, a nade wszystko filozofii postmodernistycznej (odwołującej się do koncepcji końca historii i wielkich narracji ${ }^{9}$ ), miałaby być nowa spójna ideologia, stanowiąca fundament nowego ładu społecznego i tożsamości zbiorowej. Wydają się oni przekonani, że „,społeczeństwo istnieje jako wymiana narracji - w procesie nieustającym, niegotowym, niezakończonym. Wymiana (...) polegać może na prostej wzajemności (...) lecz może także obejmować usuwanie jednych narracji i zastępowanie ich nowymi” (Czapliński 2009: 17). Można zatem mówić o zwrocie politycznym w najnowszej literaturze rosyjskiej, którego wynikiem jest nowy realizm.

\section{3. „Realizm jest naszą wiarą"10}

Nowy realizm jako prąd literacki narodził się na początku XXI wieku ${ }^{11}$ (Wołodźko-Butkiewicz 2004: 248-249). Do głosu doszli marginalizowani do tej pory autorzy, piszący o życiu przeciętnych Rosjan, między innymi Oleg

${ }^{9}$ „Wielka narracja” to pojęcie oznaczające uniwersalistyczną opowieść, zakreślającą obraz świata, porządkującą rzeczywistość i stanowiącą podstawowy układ odniesienia dla wszelkich działań ludzkich (np. nowoczesna wiara w oświeceniowy Rozum). Koniec wielkich narracji wieszczyli najważniejsi teoretycy postmodernizmu, m.in. J.F. Lyotard (1997), F. Fukuyama (1996).

${ }^{10}$ Cytat z artykułu teoretyka rosyjskiego nowego realizmu, Olega Pawłowa, Mietafizika russkoj prozy, <http://lib.ru/PROZA/PAVLOV_O/kritika1998.txt_with-big-pictures.html>, 01.06.2013 (przeł. K.U.R.).

${ }_{11}$ Dotychczas, poza pojedynczymi próbami konceptualizacji pojęcia nowego realizmu na rosyjskich konferencjach literaturoznawczych, nie powstało żadne kompletne opracowanie naukowe, dotyczące literatury tego nurtu lub niezinstytucjonalizowanego ugrupowania literackiego, występującego pod tą samą nazwą. W Rosji toczy się żywa dyskusja na temat pojęcia nowego realizmu, a uczestniczący w niej krytycy literaccy podzielili się na dwa obozy. Wśród zwolenników i obrońców młodego pokolenia znaleźli się przede wszystkim Andriej Rudalow i Walerija Pustowaja. Po stronie przeciwników, którzy zwykli nazywać je „dyktaturą chamstwa” lub „bękartami literatury rosyjskiej”, znaleźli się m.in. Siergiej Bielakow, Igor Frolow czy Michaił Bojko. Niniejszy spór opisał w dużym skrócie Andriej Moskwin we wstępie do Antologii wspótczesnego dramatu rosyjskiego (2013). 
Pawłow, Michaił Butow, Alieksiej Warłamow. Skupiali się przede wszystkim na szarzyźnie codzienności, atmosferze marazmu czy zmaganiach człowieka z przytłaczającą rzeczywistością (Wołodźko-Butkiewicz 2004: 90). W ślad za nimi zadebiutowało młode pokolenie niepokornych literacko i politycznie pisarzy: Siergiej Szargunow, Roman Sienczin, German Sadułajew, Andriej Rubanow, Michaił Jelizarow, Zachar Prilepin i inni. Nowy realizm miał być reakcją na bezideowy, według nich, literacki nurt postmodernizmu.

W programowym manifeście Siergieja Szargunowa z 2001 roku, Omрииание траура, pojawił się postulat przywrócenia literaturze jej społecznego znaczenia. Padały także pytania o egalitaryzm kultury rosyjskiej oraz zarzuty wobec literatury postmodernistycznej, oskarżanej o elitaryzm i nadmierny autotematyzm. Młodych twórców drażniła intertekstualność, fragmentaryczność, a także ekskluzywne gry literackie. Były to przede wszystkim argumenty polityczne i ideowe, autor manifestu w mniejszym stopniu zwracał uwagę na zespół cech kompozycyjnych, artystycznych czy stylistyczno-językowych, jakie miałyby cechować nową literaturę.

Wciąż trudno mówić o jednorodnym nurcie nowego realizmu. Jeśli jednak przyjąć, że elementami tworzącymi nowy kierunek literacki mogą być wspólne idee, zbieżny światopogląd artystów oraz wspólne tematy lub motywy, można traktować nowy realizm rosyjski jako osobny prąd literacki. Charakteryzowałoby go krytyczne podejście do rzeczywistości, rewizja postmodernistycznej refleksji nad społeczeństwem i kulturą oraz powrót do realizmu, rozumianego jako metoda twórcza. Ważnym komponentem nowego realizmu jest odwoływanie się do rosyjskiej tradycji literackiej - zarówno do wielkich realistycznych powieści XIX-wiecznych, jak i do rosyjskiego modernizmu i ruchów awangardowych początku XX wieku. Powrót do korzeni był wymierzony przeciw postmodernizmowi, którego reprezentanci kontestowali bądź wyśmiewali kanon rosyjskiej literatury klasycznej (Wołodźko-Butkiewicz 2004: 229-247). Według Szargunowa, zadaniem nowego pokolenia pisarzy realistów jest twórczość, która stanowiłaby aktualny komentarz do realiów społecznych, nie tracąc przy tym wysokiej wartości estetycznej. W przeciwieństwie do postmodernistów, nowi realiści nie mają zamiaru parodiować rodzimej rzeczywistości ${ }^{12}$. Pojawia się

${ }^{12}$ Powyższe sądy na temat rosyjskiego postmodernizmu oraz przemian w najnowszej literaturze rosyjskiej pochodzą ze wspomnianego manifestu Siergieja Szargunowa Отрицание 
zatem wyraźna dychotomia między literaturą rodzimą, „swoją”, która powinna być traktowana jako poważna refleksja nad rzeczywistością, a zapożyczoną, „obcą” dla rosyjskiej kultury, postrzeganą jako zlepek niejasnych, nieprzydatnych, a nade wszystko niewyszukanych artystycznie „sztuczek literackich”. Nowy realizm, zgodnie z założeniami Siergieja Szargunowa oraz wtórujących mu Walerii Pustowej (w manifeście z 2005 roku Porażency i prieobrażency. $O$ dwuch aktualnych wzgladach na riealizm) i Andrieja Rudalowa (w krytycznym szkicu z 2010 roku Katiechizis ,,nowogo riealizma". Wtoraja wotna), jest przede wszystkim zwrotem ku narodowej tradycji literackiej i oznacza „w prostej linii przynależność do rosyjskiej kultury i tradycji. Celem nowego realizmu jest ochrona narodu przed realnym zagrożeniem utraty własnej tożsamości” (Rudalow 2010).

Poprzez debiut Zachara Prilepina w 2003 roku nowy realizm zyskuje wyrazisty i radykalny odcień polityczny i ideologiczny. W swoich licznych artykułach na temat założeń nowego realizmu autor deklaruje, że głównym zadaniem pisarzy społeczników, skupionych wokół tego nieformalnego ugrupowania, jest symboliczne i faktyczne obalenie władzy oraz zaprowadzenie nowego ładu. Fundamentem twórczości ma być więc także antysystemowość. Zmiana społeczna powinna się dokonywać w realnej walce politycznej pozostającej w sojuszu z literaturą.

Nowi realiści określają się mianem awangardy literackiej. Hasła nawołujące do utworzenia wspólnej literacko-społecznej, antysystemowej barykady przywodzą na myśl porewolucyjne ugrupowanie Lewego Frontu Sztuki $^{13}$. Oprócz częściowo zbieżnych, skrajnie lewicowych i radykalnie narodowych ideałów obie formacje łączy przede wszystkim przekonanie o podstawowej funkcji sztuki, którą miałoby być poszerzanie świadomości społecznej i pielęgnowanie idei rewolucji. W centrum zainteresowania obu awangard znajduje się rzeczywiste, współczesne społeczeństwo.

mpaypa, dostępnego on line < http://magazines.russ.ru/novyi_mi/2001/12/shargunov.html>, 13.03.2014.

13 Lewy Front Sztuki (ros. ЛЕФ: Левый Фронт Искусств) - ugrupowanie artystyczne, działające w Moskwie, Odessie i innych miastach w latach 1922-1928. Opowiadało się za „literaturą faktu”, ukazującą rewolucyjne przemiany społeczne, i za twórczością ,„proletariacką”. Głównym przedstawicielem LEF-u był Włodzimierz Majakowski. 


\section{4. „Nowy Gorki się zjawil”14}

Pierwszym rzecznikiem idei poszukiwań wielkiej narracji, wskazującej społeczeństwu spójny obraz świata, jest Zachar Prilepin. Jako zagorzały oponent tezy, że człowiek powinien pragnąć jedynie własnej wolności, buntuje się on przeciwko porządkowi liberalno-demokratycznemu, zbudowanemu na fundamentach wolnego rynku oraz przeciwko wpisanemu weń założeniu o ekspansywnym charakterze ludzkiej natury. Osią nowej rosyjskiej narracji ma być, w jego opinii, konflikt, bunt i opór oraz towarzysząca im propozycja nowego porządku społecznego. W prozie Prilepina powracają wciąż te same diagnozy społeczno-polityczne: kapitał, który przekracza granice państw narodowych, jest przyczyną zaniku ich suwerenności, relatywizm zrównuje tożsamości i przekształca tradycyjną wiarę czy religię w styl życia, sieciowy wyzysk pogłębia dystanse społeczne, liberalne relacje seksualne niszczą rodzinę i równowagę demograficzną społeczeństwa. Ponowoczesność odbiera miejsca pracy, dobytek, ciepło wspólnoty oraz prawo do dumy narodowej.

Zachar Prilepin to jeden z najbardziej popularnych pisarzy rosyjskich ostatnich lat. Zadebiutował w 2004 roku powieścią Patologie, poświęconą wojnom czeczeńskim. Jest laureatem kilkunastu prestiżowych nagród, a także bardzo płodnym i aktywnym publicystą. Prilepin to także zdeklarowany radykalny opozycjonista, członek koalicji antykremlowskiej Inna Rosja oraz aktywny działacz zdelegalizowanej partii narodowo-bolszewickiej. Ta artystyczno-polityczna organizacja, zwana też „sojuszem ekstremistów”, miała być pierwszą rosyjską „opozycją antysystemową”, która zrywała z podziałem na lewicę i prawicę.

Podstawą niniejszej analizy są powieści Patologie (2004), Sańkja (2006) oraz Cziornaja obiezjana (Черная обезьяна) (2011), a także zbiór opowiadań Wosmiorka (Восьмерка) (2012) oraz tom publicystyki I k nam jediet Pierieswiet. Otcziot za nulewyje (И к нам едет Пересвет. Отчет за нулевые) z lat 2000-2011. Celowo wyeksponowano problemy społeczne i polityczne, jakie porusza Prilepin, nie zostały natomiast podjęte rozważania dotyczące poetyki i estetycznej strony jego twórczości.

${ }^{14}$ Wypowiedź rosyjskiego krytyka literackiego Pawła Basińskiego na temat twórczości Prilepina <http://www.rg.ru/2006/05/15/sanjka.html>, 01.06.2013. 


\section{Kto winien? ${ }^{15}$}

Proza Prilepina koncentruje się wokół problemów społeczeństwa rosyjskiego. Głównym bohaterem jego powieści i opowiadań rzadko bywa jednostka. Na pierwszy plan wysuwa się zbiorowość, kolektyw. Nawet jeśli pojawia się centralna postać utworu, to pozostaje ona przypadkowym reprezentantem ogółu. Współczesne społeczeństwo rosyjskie jawi się zaś jako odpodmiotowione i bierne, amorficzna masa, którą można formować w dowolny sposób. Prilepin wielokrotnie podkreśla, że naród rosyjski został pozbawiony swojej najważniejszej cechy - energii - a wraz z nią przypisywanego mu dionizyjskiego pierwiastka, odpowiedzialnego za wolę buntu i rewolucji. Według pisarza winna tej sytuacji jest władza, która działając w ramach neoliberalnego ustroju, wyrwała własne społeczeństwo z gruntu, w którym było ono zakorzenione.

Otaczająca Rosjan rzeczywistość jest opresyjna - kwestie socjalne nie dają większych perspektyw na odnalezienie życiowej równowagi, a polityczne zamykają drogę społecznym zmianom. Bohaterowie Prilepinowskiej prozy borykają się z bezrobociem, z kolei zatrudnieni zarabiają zbyt mało. To ludzie o niskim statusie społecznym, robotnicy, pielęgniarki, nauczyciele itd. Prilepin idealizuje w swoich książkach tę warstwę społeczną - utożsamia ją z ludem rosyjskim, upatrując w niej nosicieli owego niedookreślonego pierwiastka rosyjskości. Motyw ukrytych wśród ludu najcenniejszych wartości oraz koncepcja rosyjskiego narodnictwa jest eksploatowana przez partię narodowych bolszewików ${ }^{16}$. Najbardziej idealizowani przez Prilepina są tzw. ludzie gleby - warstwa chłopska, której, zgodnie z tradycją rosyjskiej myśli społeczno-filozoficznej, nadaje się cechy magiczne (Bierdiajew

15 Tytuł utworu Aleksandra Hercena (oryginalne wydanie 1846; przekł. tytułu K.U.R.).

16 Ruch polityczno-artystyczny narodowych bolszewików łączy w sobie elementy nacjonalizmu i bolszewizmu. Podbudową ideową ruchu jest „,antyzapadnicka” rosyjska doktryna geopolityczna, zapoczątkowana w kręgu antybolszewickiej „białej emigracji” między rokiem 1917 a latami 20. XX wieku (m.in. N. Trubietskoj, L. Gumilow i N. Bierdiajew), której przedstawiciele nie czuli związku cywilizacji rosyjskiej z zachodnią. Wbrew emigrantom, krytykującym Rosję Radziecką z pozycji kultury zachodniej, doktryna eurazjatycka głosiła, że rosyjska kultura stanowi połączenie elementów słowiańskich i azjatyckich, a więc geopolitycznie i kulturowo Rosja miałaby stanowić „,trzeci kontynent” między materialistycznym i dekadenckim Zachodem a Orientem (definicja Adama Wielomskiego, <http://metapedia.konserwatyzm.pl/ wiki/Eurazjatyzm>, 18.06.2013). 
2005: 12). W ich obrazie odnaleźć można odwołania do tradycji rosyjskich jurodiwych czy prawosławnych świętych. To oni przechowują wartości związane z patriarchatem, porządkiem, równowagą, wreszcie - z zapomnianym poczuciem dumy. Także tej grupy dotyczy jednak zagrożenie utraty „rosyjskości”. Gleba bowiem, na której wzrasta lud, jest coraz bardziej jałowa. Konfrontacja z opresyjną rzeczywistością sprawia, że liczba „ludzi gleby" - mieszkańców idealnej, nieskażonej krainy - stale się zmniejsza. Prilepinowskiemu światopoglądowi przyświeca ultranarodowe hasło „krew i gleba"17.

Najbardziej krytykowaną przez Prilepina warstwą społeczną jest natomiast, rodząca się powoli w postsocjalistycznej Rosji, liberalna klasa średnia. Jej przedstawiciele - dobrze sytuowani, wykształceni i obnoszący się ze swoją pozycją społeczną - są $\mathrm{w}$ powieściach autora przedstawiani jako współwinni temu, co złe w obecnej rzeczywistości. Prilepin z łatwością pozwala swoim bohaterom odbierać klasie średniej jej majątek i oddawać go ludowi. Powiązane z klasą średnią elity kulturowe są przez tychże bohaterów (na ogół zaangażowanych politycznie) dyskredytowane, a ostatecznie jednoznacznie sądzone i karane. Główne zarzuty, wysuwane pod ich adresem, to oddalenie się od społeczeństwa oraz przedkładanie interesów własnych nad wspólnotowe cele.

Kolejną kwestią, podejmowaną przez Prilepina, jest postępująca alienacja prowincji ${ }^{18}$. Pisarz krytykuje protekcjonalną postawę Moskwy wobec mieszkańców najdalszych zakątków kraju. Prowincja, jego zdaniem, zachowała najbardziej rosyjski kształt, a jej mieszkańcy wyraźnie różnią się od mieszkańców stolicy. Ci ostatni świadomie odrywają się od rosyjskich korzeni, pozwalając, by kraj zalewała fala zachodniej kultury masowej, kłamstw polityków, frustracji i zniecierpliwienia. Element ,antyzachodni” jest tu niezwykle istotny. Zgodnie z ideologią radykalnej opozycji symboliczna Ameryka (pod tym hasłem, jak się zdaje, kryje się szersza niechęć do wszystkiego, co euroatlantyckie lub prozachodnie) jawi się jako monstrum,

${ }^{17}$ Nawiązujące wprawdzie do nazistowskiego hasła „Blut und Boden”, ale w interpretacji Prilepina raczej narodnickie, narodowe, nacjonalistyczne niż stricte nazistowskie.

${ }^{18} \mathrm{~W}$ rosyjskim dyskursie publicznym popularne stało się w ostatnich latach dychotomiczne zestawianie Moskwy jako centrum i pozostałych obszarów Federacji Rosyjskiej jako prowincji. 
pożerające prawdę i autentyczność - innymi słowy, rdzennie rosyjską moralność i obyczajowość.

$\mathrm{Na}$ kartach Prilepinowskiej prozy powraca także problem niedostatecznego zaangażowania politycznego społeczeństwa rosyjskiego. Od ponad dziesięciu lat nie bierze ono aktywnego udziału w polityce swojego kraju, a wszelkie protesty nie pozostawiają złudzeń co do możliwości zmiany. Bohaterowie powieści Prilepina są najczęściej buntownikami, skupionymi wokół środowisk opozycyjnych. Nowi dysydenci, choć nie zawsze zgodni co do szczegółów przyszłego ładu, twierdzą, że rewolucja jest jedyną metodą, pozwalającą na urzeczywistnienie zmian społecznych. Niejednokrotnie manifestują to przekonanie, uciekając się do przemocy.

Istotną rolę $\mathrm{w}$ poszukiwaniu tożsamości społeczeństwa odgrywa konieczność zmierzenia się z kulturowym i społecznym dziedzictwem Związku Radzieckiego. W tekstach Prilepina powraca problem pamięci zbiorowej współczesnych Rosjan jako jednego z ważniejszych komponentów ich wspólnej tożsamości. Bohaterowie jego prozy najczęściej pamiętają zaledwie schyłek ZSRR, ale jednocześnie drażni ich współczesny dyskurs publiczny (szczególnie ten wspierany przez elity kulturalne, powiązane ze wspomnianą wyżej liberalną klasą średnią) próbujący dyskredytować wagę społeczną tego okresu. Młodzi buntownicy, aspirujący do polityki, nie widzą na obecnej scenie politycznej miejsca dla starych działaczy komunistycznych, ale jednocześnie w pewnej mierze próbują dowartościować Związek Radziecki. Zwracają przy tym uwagę przede wszystkim na znaczenie rozbudowanego systemu zabezpieczeń socjalnych, będącego jednym z kluczowych elementów poprzedniego ustroju. Zdaniem Prilepina, Związek Radziecki - w przeciwieństwie do obecnego systemu - dowartościowywał warstwy niższe zarówno na płaszczyźnie symbolicznej (jako „państwo robotników i chłopów", nadawał ludowi uprzywilejowaną podmiotowość), jak i socjalnej (zapewniał szerokie możliwości awansu społecznego). Prilepin przypomina, że to właśnie z ludu wywodziła się plejada uznanych radzieckich uczonych, wojskowych, artystów i intelektualistów. Według pisarza właśnie to, co radzieckie, jest kwintesencją ludowego uczestnictwa w historii, a powrót do tych ideałów może się przyczynić do budowy egalitarnego społeczeństwa.

Najbardziej dotkliwą krytykę Prilepin wymierza we władzę polityczną. W literackim portrecie jest ona skorumpowana, zachłanna, nieuczciwa, 
antyspołecznie zorientowana. Protagoniści Prilepinowskiej prozy widzą w działaniach elit rządzących politykę antyrosyjską (według nich właśnie za sprawą współczesnych elit Rosja straciła znaczenie na arenie międzynarodowej i nie ma już pozycji mocarstwa).

\section{Co robić? ${ }^{19}$}

Pozostaje pytanie, jaki kształt przybierze nowa ,wielka narracja” rosyjska. Prilepin, jako zwolennik narodowego bolszewizmu, operuje swoistą racjonalno-emocjonalną mieszanką pojęć i postaw (od lewicowych po prawicowe, od konserwatyzmu po elementy liberalne). Jego celem jest stworzenie koncepcji rosyjskiego modelu socjalizmu bądź komunizmu narodowego. Aspekt lewicowy w omawianej twórczości to legitymacja państwa opiekuńczego. Dążenie do porządku, hierarchii, odwołania do najważniejszych tradycyjnych wartości (prawosławie, wspólnota i patriarchat), chęć przywrócenia wielkiego, stabilnego, liczącego się na arenie międzynarodowej państwa z silną, bezkompromisową władzą, to inspiracje prawicowe. Najważniejsza wydaje się jednak moc niszczycielskiego buntu - żywioł rewolucyjny, który, wzniecając światowy pożar, niszczy i oczyszcza wszystko dookoła. Podbudową modelu nowego rosyjskiego ładu są elementy filozofii XIX-wiecznych narodników, późniejszych eserowców, w końcu wczesnych bolszewików. Podstawową wartością w wymienionych ruchach jest lud jako nosiciel prawdy ${ }^{20}$.

Proza Zachara Prilepina, wysoko oceniana przez krytyków pod względem artystycznym, składa się z komponentów nowej ideologii. Miałaby ona doprowadzić do ufundowania nowej tożsamości, będącej hybrydą najcenniejszych przed- i porewolucyjnych elementów rosyjskiej

19 Tytuł społecznej powieści Nikołaja Czernyszewskiego (wydanie polskie 1951).

${ }^{20} \mathrm{O}$ rosyjskim pojmowaniu i poszukiwaniu prawdy pisał m.in. Marian Broda w artykule Sacrum-moc-władza-wiedza-ład-tożsamość-legitymizacja... O rosyjskim pojmowaniu prawdy (2007). W tym kontekście prawda wyraża ideał etyczny oraz pożądany i wciąż poszukiwany komponent zbiorowej tożsamości Rosjan. Sposób pojmowania przez Rosjan prawdy rozpatruje się ,w kontekście prawosławia, leżącego w znacznym stopniu u podstaw, odmiennej od Zachodu, specyfiki rosyjskiej mentalności, duchowości, postaw życiowych, tradycji intelektualnej i dziedzictwa kulturowego" (cf. Broda 2007). Zgodnie z tą tradycją ,odsłonięcie tajonych prawd ma uzdrawiać i naprawiać społeczeństwo" (cf. de Lazari 1995). 
samoświadomości narodowej. Prilepina można określić jako pisarza antysystemowego. Kontestuje on system neoliberalny, często określany jako darwinizm społeczny. Pisarz zarzuca mu intencjonalną eliminację najsłabszych warstw społecznych oraz obcość wobec konstytutywnej dla Rosji wspólnotowości. Krytyce poddawane są także współczesne elity rządzące jako najwięksi wrogowie Prilepinowskiego ludu. Obecny lider państwa to zaledwie menedżer, przedstawiciel dyskredytowanej przez narodowych bolszewików, obcej, technokracji. Pieczę nad państwem sprawować powinien człowiek kultury, patrzący na Rosję z metafizycznej perspektywy. Ów postulat koresponduje z przekonaniem autora o literaturocentrycznym charakterze kultury rosyjskiej. Zachar Prilepin postuluje również sprawiedliwą ocenę Związku Radzieckiego, traktując pamięć o nim jako istotny składnik społecznej tożsamości. Występuje nie tylko z pozycji krytyka obecnego systemu, ale stara się również być rzecznikiem ludu, proponując radykalne, rewolucyjne rozwiązania dla obecnych problemów kraju.

\section{Literatura}

Bierdiajew N., 2005, Źródla i sens komunizmu rosyjskiego, Kęty.

Bierg M., 2000, Litieraturokratija, Problema priswojenija pierieraspriedielienija wlasti w litieraturie, Moskwa, <http://www.mberg.net/litkrat/>, 25.12.2013.

Bourdieu P., 2001, Reguly sztuki. Geneza i struktura pola literackiego, przeł. A. Zawadzki, Kraków.

Broda M., 2007, Sacrum-moc-władza-wiedza-ład-tożsamość-legitymizacja... O rosyjskim pojmowaniu prawdy, „Sofia” nr 7, s. 101-109.

Burzyńska A., Markowski M.P., 2006, Teorie literatury XX wieku: podręcznik, Warszawa.

Czapliński P., 2009, Polska do wymiany. Późna nowoczesność i nasze wielkie narracje, Kraków.

Czernyszewski N., 1951, Co robić, przeł. J. Brzęczkowski, Warszawa.

Dunin K., 2004, Czytając Polskę. Literatura polska po roku 1989 wobec dylematów nowoczesności, Warszawa.

Fukuyama F., 1996, Koniec historii, przeł. T. Bieroń, M. Wichrowski, Poznań.

Iwanowa N., 2003, Skrytyj siużet. Russkaja litieratura na pieriechodie czieriez wiek, Petersburg.

Iwanowa N., 2011, Russkij kriest. Litieratura i czitatiel'w naczale wieka, Moskwa. de Lazari A., 1995, Mentalność rosyjska. Stownik, Katowice. 
Lyotard J.F., 1997, Kondycja ponowoczesna, przeł. M. Kowalska, J. Migasiński, Warszawa.

Moskwin A., 2013, Antologia wspótczesnego dramatu rosyjskiego. Nowy Realizm, t. 1, Warszawa.

Nakoneczny T., 2007, Rosyjska tożsamość narodowa wobec modernizacji literatury, „Porównania” nr 4, s. 83-93.

Nycz R., 2006, Wprowadzenie, w: Kulturowa teoria literatury. Glówne pojęcia i proble$m y$, red. R. Nycz, M.P. Markowski, Kraków.

Olejniczak J., Knapek R., Szumna M., 2012, Polityczność literatury. Polityczność literaturoznawstwa. Gramatyka sprzeciwu, Katowice.

Prilepin Z., 2008, Sańkja, przeł. K. Wańczyk, Wołowiec.

Prilepin Z., 2010, Patologie, przeł. M. Buchalik, Wołowiec.

Prilepin Z., 2011, Cziornaja obiezjana, Sankt-Petersburg.

Prilepin Z., 2011, I k nam jediet Pierieswiet. Otcziot za nulewyje, Sankt-Petersburg.

Prilepin Z., 2012, Wosmiorka, Sankt-Petersburg.

Radiszczew A., 1954, Podróży z Petersburga do Moskwy, przeł. S. Pollak, Wrocław.

Rudalow A., 2010, Katiechizis ,nowogo riealizma”. Wtoraja wotna, „Rossijskij pisatiel", <http://www.rospisatel.ru/konferenzija/rudaljev.htm>, 05.05.2014.

Sieradzan P., 2008, Aksamitni terroryści. Narodowy bolszewizm w Federacji Rosyjskiej, Warszawa.

Smoleń M., 2010, Rosyjska inteligencja liberalna i radykalna w XIX i na poczq̨tku XX wieku. Poglądy, oceny, opinie, Kraków.

Wołodźko-Butkiewicz A., 1995, Pasierbowie Rosji. O prozaikach trzeciej emigracji, Warszawa.

Wołodźko-Butkiewicz A., 2004, Od pieriestrojki do laboratoriów netliteratury. Przemiany we wspótczesnej prozie rosyjskiej, Warszawa.

Ziętek-Maciejczyk E., Cieliczka P., 2006, Literatura zaangażowana - koncepcje, programy, realizacje. Czy potrzebna nowa definicja?, Warszawa. 
